\title{
Hydrologic System Protection by Decentralized Wastewater Treatment Technologies in Jordan
}

\author{
Naser Almanaseer \\ Faculty of Engineering, Civil Engineering Department, Al-Balqa Applied University, Al-Salt, 19117 Jordan
}

\begin{abstract}
The nine different technologies are constructed at the pilot scale in one experimental site at Al-Balqa Applied University and use the same wastewater characteristics as the inlet. Monthly samples were collected from the inlet and outlet of nine different decentralized wastewater treatment technologies for three years (June 2016-June 2019). The samples were analyzed for physical, chemical, and biological parameters including TSS, Turbidity, pH, COD, $\mathrm{DO}, \mathrm{NH}_{4}, \mathrm{NO}_{3}, \mathrm{TN}, \mathrm{BOD}$, and E. coli. Removal efficiencies for the nine technologies are obtained for COD, BOD, TN, and TSS to be above 95\%. $\mathrm{NH}_{4}$ the removal efficiencies for the nine technologies vary and found to be in the range of 27 to $76 \%$ while for the $E$. coli in the range of 65 to $95 \%$. Further, data on energy consumption were collected for each technology and found for the nine investigated technologies in the range of 0.03 to 0.30 Jordan Dinars per treated cubic meter. The investigated technologies were evaluated, and the best options were endorsed. It is concluded that the adaptation of decentralized wastewater treatment will certainly help protect the hydrologic system in Jordan especially in the high lands where significant groundwater recharge occurs and a considerable amount of surface water flows towards Jordan Valley and collection dams.
\end{abstract}

Keywords: Wastewater, decentralized wastewater treatment, contamination, pollution, innovative technologies, removal efficiency.

\section{Introduction}

Jordan depends mainly on groundwater for domestic uses and blended reclaimed water with surface water for irrigation (Fach et al, 2010). Major cities are served with centralized wastewater collection systems but this is not the case in rural areas. Establishing and operating collection and treatment systems in rural areas are not economically feasible because the users are highly scattered and the topography is significantly variable (Brunner et al., 2018). The situation is further complicated because most of Jordan's renewable groundwater resources are located in the high lands, mostly on top of limestone aquifers. These aquifers are vulnerable to groundwater contamination by cesspits (Burde et al., 2001). Lately, the government of Jordan is dedicating part of their attention and budget to promote decentralized wastewater treatment as an option for groundwater protection and therefore sustainable hydrologic system (Hussein, 2019).

Decentralized wastewater systems are considered for communities up to 5000 inhabitants (Nanninga et al., 2012). For more than this number, centralized wastewater collection and treatment systems are more suitable (Massoud et al., 2008). To be specific, decentralized wastewater systems are suitable for communities in remote areas, hotels, industries, and households in rural areas (Chong et al., 2012). Another important aspect of decentralized wastewater treatment is the reuse part (MWI 2016). Due to the water shortage, it is very useful for residents and farmers to have access to reclaimed water that can be used for supplementary irrigation. However, what is the type of technology end-users should adopt and what cost, and whether it is safe and sustainable (Khattiyavong et al., 2019). Based on these facts, this research is performed to partially answer these questions and to provide feasible clarifications that may help academia, managers, and end-users form an adequate decision based on a scientific approach.

Non-conventional water resources can be used for food production systems after proper treatment for the rehabilitation of marginal and degraded lands in the Middle East and North Africa (Hussain et al., 2019). Different wastewater technologies are commercially used for the treatment of municipal as well as industrial wastewater (MWI, 2016).

Wetland technologies, SBR, septic tank, modified septic tank, and biofilm systems are successfully implemented in Jordan in one of the important demonstration research centers and in several cities in Jordan (Wang et al., 2019). Furthermore, it is necessary to ensure the local water quality required, a cost-effective treatment, sustainability, and protection of public health. The development and adaptation of these technologies and solutions have considered the local conditions and climate change (MWI, 2019).

Received on November 2, 2019; accepted on February 18, 2020 Correspondence concerning this article should be addressed to Naser Almanaseer (E-mail address: almanaseer@bau.edu.jo, ORCiD ID of Naser Almanaseer https://orcid.org/0000-0003-0125-9615. 
The general classification of decentralized wastewater treatment systems includes the following (Singh et al., 2014):

- Natural treatment systems

Aerobic systems: Suspended growth, attached growth, and Combined suspended and attached growth. Anaerobic systems: Suspended growth, Attached growth. Combined (aerobic/anaerobic/natural) systems. Anaerobic-aerobic, Anaerobic-natural, and Anaerobicaerobic-natural

Following is a brief description of the investigated technologies constructed at the research facility at Al-Balqa Applied University during this research:

- $\quad$ Septic Tanks and Modified Sept Tanks Systems

The system is based on a modification of the conventional septic tank by including an integrated aerated-settling chamber. Two modules of bacterial growth (suspended and attached) are tested to treat domestic wastewater (Abbasi et al., 2018). Unlike the suspended growth reactor, the anaerobic/aerobic fixed bed reactor contains corrugated plastic sheets, where the microorganisms are attached to the surface of the packing material (Ambica and Raman, 2015).

- $\quad$ Sequencing Batch Reactor (SBR) Systems, SBR is a discontinuously operated fill- and draw-activated sludge process. The unit consists of a clear water pump, aerator and de-sludging pump (Beuna et al., 1999). All the reactors are operated in the mode with feed, anaerobic, aerobic, settling and decanting phases and therefore all biological, oxidation, sedimentation, nitrification, and de-nitrification processes occur in a single tank. On the other hand, a continuous batch reactor designed to reduce electrical consumption. Two settling tanks designed in a way to separate the suspended solids from the treated water. Aeration, de-sludging, and feeding are done by a small compressor.

a. Wetland Systems: Multi-stage Single-pass Vertical Filter system that was designed to produce high-quality effluent passively. The system consists of a septic tank (primary treatment), first stage vertical filter (secondary treatment and nitrification), organic denitrification reactor (removal of nitrate), and a second stage vertical filter (pathogen reduction and further polishing) (Vymazal, 2005).

b. A recirculating vertical filter system that is consists of a septic tank for primary treatment, followed by a recirculation tank. Effluent is pumped from the recirculation tank onto the vertical filter before then flowing through a flow splitting device from where a portion of the effluent is returned to the recirculation tank while the rest leaves the system and is used for irrigation. The system is designed to treat $2 \mathrm{~m}^{3} /$ day (Vymazal, 2010) and (Masia and Martinuzzi, 2007).

- $\quad$ French Systems

The French version of vertical-flow constructed wetlands is characterized by treating directly raw wastewater on a first-stage filter (Prost-Boucle and Molle, 2015). The advantage of the French system is that it takes raw sewage directly to its first stage and treats the primary sludge on the surface of the first stage beds. This greatly facilitates sludge management as compared to systems which need to deal with primary sludge (Esser et al., 2014).

\section{Materials and Methods 1.1 Experiment Design}

The experiments were designed to critically analyze and discuss data and results obtained from experimental methods to assess the microbial population dynamics in wastewater treatment technologies, and to evaluate the process performance and characteristics of physical, chemical, and biological wastewater treatment processes. This research is carried out in the above-mentioned research facility at Al-Balqa Applied University. Samples were collected on the same day and time each month, and the analysis was carried out in the laboratory which is prepared with all necessary equipment and test kits. The data is examined, validated, and finally approved before its stored and used for analysis. Some tests were occasionally re-taken to ensure data reliability and accuracy. The technologies monitored were selected to be all the available technologies in the facility, the inlet, and outlet sampling points were the same for the entire period of sampling to ensure consistency.

The design parameters were selected to cover all concerns and to answer all possible research questions Domestic raw water in the research facility is unlikely to have heavy metals or pharmaceutical residuals. However, one test was made at the beginning of the sampling period to confirm this fact. The samples were analyzed for physical, chemical, and biological parameters including Total Suspended Solids (TSS), Turbidity, Potential Hydrogen (pH), Chemical Oxygen Demand (COD), Dissolved Oxygen (DO), Ammonium $\left(\mathrm{NH}_{4}\right)$, Nitrate $\left(\mathrm{NO}_{3}\right)$, Total Nitrogen (TN), Biological Oxygen Demand (BOD), and Escherichia coli (E. Coli) all in mg per liter. Further, data on energy consumption were collected for each technology. As mentioned above, the experiments carried out over three years on nine different decentralized wastewater technologies installed in the research facility. The systems dimensions are standards for the nine technologies with 3 meters long, 2 meters width and 1.5 meters depth. The flow rate is calibrated to be 2 cubic meters per 24 hours and controlled with the control panel. 


\subsection{Analysis}

The main objective of this research is highly connected to the identification of the most efficient technology considering technical and economical constraints. Hence, it is important to compare the analysis across the different technologies, with proper interpretations and reasonable conclusions. It is worth mentioning that the effluent not only controlled by the process itself but with external conditions such as climatic conditions and raw wastewater characteristics (Almanaseer et al, 2012). Hence, it is important to consider these facts when trying to establish trends and variability among the different variables. The correlation was considered, graphical representation as well. More elaboration on this and pictorial representations are presented in the result section.

\section{Results and discussion}

Table 1 shows a summary of the average monthly values for the different parameters throughout this research (June 2016-June 2019). Significant variations in effluent water quality are observed among different technologies. However, all the technologies fulfill the required standards for reclaimed water reuse. Also, Figure 1 shows graphical representations of the performance for the nine different technologies. The performance is calculated based on eight parameters relative to the water quality of the raw water before and after treatment. All parameters are found below the reuse standard. But, there is noticeable variability among the different technologies in terms of their performance. This is normal since different technologies operate different principals and advanced processes and influenced differently by local conditions such as raw wastewater characteristics and climatic variations. Table 2 shows the average, minimum, maximum, and standard deviation of the monthly data for the nine examined technologies

Table 1 Long-term average values for the different technologies

\begin{tabular}{|c|c|c|c|c|c|c|c|c|c|}
\hline Technology & COD & BOD & $\mathrm{TN}$ & $\mathrm{NH}_{4}$ & $\mathrm{NO}_{3}$ & TSS & DO & $\mathrm{pH}$ & Turbidity \\
\hline Septic Tank & 54.0 & 16.2 & 65.3 & 14.1 & 1.2 & 20.3 & 2.8 & 7.3 & 13.2 \\
\hline Modified Septic Tank & 69.9 & 18.6 & 63.1 & 45.5 & 1.4 & 32.5 & 2.9 & 7.5 & 11.7 \\
\hline Sequencing Batch Reactor with Ultraviolet (SBR-UV) & 61.4 & 15.8 & 93.0 & 30.4 & 6.8 & 32.5 & 3.2 & 7.5 & 12.8 \\
\hline $\begin{array}{l}\text { Sequencing Batch Reactor with Ultraviolet } \\
\text { manufactured by PUROO Company (SBR-PUROO) }\end{array}$ & 46.8 & 16.8 & 46.1 & 26.7 & 1.7 & 24.8 & 3.3 & 7.6 & 12.0 \\
\hline Vertical Wetland (V-Wetland) & 25.0 & 10.0 & 105.2 & 0.9 & 65.2 & 19.2 & 5.0 & 7.6 & 2.5 \\
\hline Recirculated Wetland (R-Wetland) & 106.0 & 21.5 & 84.6 & 9.8 & 47.6 & 34.3 & 3.2 & 7.3 & 19.3 \\
\hline Aerated Wetland & 20.7 & 11.0 & 46.6 & 0.6 & 36.6 & 18.0 & 7.0 & 8.0 & 3.5 \\
\hline Second wetland & 34.1 & 16.3 & 33.3 & 4.1 & 27.1 & 16.6 & 4.6 & 8.0 & 2.8 \\
\hline French aerated wetland & 15.8 & 8.3 & 30.1 & 0.9 & 25.1 & 16.6 & 7.4 & 8.3 & 1.5 \\
\hline Raw wastewater & 863.0 & 612.3 & 128.4 & 69.7 & 0.7 & 805.5 & 0.6 & 7.1 & 331.2 \\
\hline
\end{tabular}

On the other hand, the removal efficiency as a percentage showed slight variations among the different technologies but overall the removal efficiency is high and promising. For TN, the removal efficiency is less but this is suitable for reuse where reclaimed water is rich with nitrogen to compensate for fertilizers necessary for plant growth. Removal for DO, pH, and Turbidity is not considered since the focus is on the biochemical parameters. The energy consumption varies where wetland technologies consume less energy in comparison to the septic tank and SBR technologies and the removal efficiency of the nine technologies (Table3). 
Table 2 Minimum, maximum, and standard deviation of the monthly data for the nine technologies

\begin{tabular}{|c|c|c|c|c|c|c|c|c|c|c|c|}
\hline Technology & Statistics & COD & BOD & $\mathbf{T N}$ & $\mathbf{N H}_{4}$ & $\mathrm{NO}_{3}$ & TSS & E-coli & DO & pH & Turbidity \\
\hline \multirow{4}{*}{ Septic Tank } & Average & 54.0 & 16.2 & 65.3 & 14.1 & 1.2 & 20.3 & 94354 & 2.8 & 7.3 & 13.2 \\
\hline & STD & 4.7 & 2.6 & 10.0 & 7.4 & 1.3 & 4.7 & 23273 & 0.7 & 0.8 & 4.0 \\
\hline & $\operatorname{Max}$ & 60.8 & 22.0 & 81.3 & 29.4 & 4.7 & 30.0 & 158500 & 4.7 & 7.7 & 22.1 \\
\hline & Min & 44.3 & 12.0 & 50.8 & 4.8 & 0.3 & 14.0 & 67600 & 2.0 & 4.7 & 8.2 \\
\hline \multirow{4}{*}{$\begin{array}{l}\text { Modified } \\
\text { Septic Tank }\end{array}$} & Average & 69.9 & 18.6 & 63.1 & 45.5 & 1.4 & 32.5 & 70685 & 2.9 & 7.5 & 11.7 \\
\hline & STD & 9.2 & 2.8 & 6.8 & 9.5 & 1.4 & 8.2 & 24674 & 0.6 & 0.1 & 3.7 \\
\hline & Max & 86.9 & 25.0 & 72.0 & 63.1 & 5.2 & 44.0 & 133400 & 3.7 & 7.7 & 16.4 \\
\hline & Min & 54.6 & 14.0 & 50.2 & 28.6 & 0.3 & 12.0 & 43100 & 2.0 & 7.2 & 4.3 \\
\hline \multirow{4}{*}{ SBR-UV } & Average & 61.4 & 15.8 & 93.0 & 30.4 & 6.8 & 32.5 & 547 & 3.2 & 7.5 & 12.8 \\
\hline & STD & 13.2 & 5.8 & 20.2 & 7.9 & 3.5 & 9.7 & 115 & 0.7 & 0.2 & 9.9 \\
\hline & $\operatorname{Max}$ & 77.7 & 29.0 & 138.6 & 39.4 & 13.2 & 50.0 & 805 & 5.3 & 7.9 & 44.2 \\
\hline & Min & 27.2 & 10.0 & 51.3 & 8.6 & 2.2 & 16.0 & 359 & 2.1 & 7.1 & 4.4 \\
\hline \multirow{4}{*}{ SBR-PUROO } & Average & 100 & 30 & 45 & 0.0 & 30 & 50 & 100 & 2 & 9 & 10 \\
\hline & STD & 500 & 200 & 70 & 0.0 & 45 & 200 & 1000 & 0.0 & 9 & 0.0 \\
\hline & Max & 150 & 60 & 70 & 0.0 & 80 & 60 & 1000 & 1 & 9 & 0.0 \\
\hline & Min & 50 & 15 & 45 & 5 & 30 & 50 & 2 & 2 & 9 & 2 \\
\hline \multirow{4}{*}{ V-Wetland } & Average & 25.0 & 10.0 & 105.2 & 0.9 & 65.2 & 19.2 & 569 & 5.0 & 7.6 & 2.5 \\
\hline & STD & 3.8 & 2.9 & 19.0 & 0.6 & 18.6 & 3.6 & 68 & 1.0 & 0.2 & 1.3 \\
\hline & $\operatorname{Max}$ & 34.6 & 15.0 & 132.8 & 2.0 & 101.2 & 26.0 & 670 & 6.5 & 7.8 & 6.2 \\
\hline & Min & 20.4 & 6.0 & 61.1 & 0.2 & 42.6 & 14.0 & 471 & 3.5 & 7.3 & 1.2 \\
\hline \multirow{4}{*}{ R-Wetland } & Average & 106.0 & 21.5 & 84.6 & 9.8 & 47.6 & 34.3 & 285962 & 3.2 & 7.3 & 19.3 \\
\hline & STD & 20.8 & 2.6 & 15.2 & 10.1 & 12.5 & 5.4 & 76874 & 0.6 & 0.2 & 5.2 \\
\hline & Max & 140.0 & 25.0 & 127.6 & 33.4 & 69.2 & 44.0 & 435200 & 4.0 & 7.6 & 25.6 \\
\hline & Min & 55.4 & 16.0 & 68.6 & 2.6 & 31.6 & 28.0 & 160200 & 2.5 & 7.0 & 12.3 \\
\hline \multirow{4}{*}{$\begin{array}{l}\text { Aerated } \\
\text { Wetland }\end{array}$} & Average & 20.7 & 11.0 & 46.6 & 0.6 & 36.6 & 18.0 & 600 & 7.0 & 8.0 & 3.5 \\
\hline & STD & 6.7 & 2.3 & 2.4 & 0.3 & 4.2 & 13.4 & 58 & 0.9 & 0.1 & 1.7 \\
\hline & Max & 35.0 & 15.0 & 49.6 & 1.1 & 44.8 & 50.0 & 693 & 7.9 & 8.1 & 6.3 \\
\hline & Min & 13.3 & 8.0 & 42.6 & 0.0 & 31.2 & 8.0 & 512 & 5.2 & 7.7 & 1.3 \\
\hline \multirow{4}{*}{ Second wetland } & Average & 34.1 & 16.3 & 33.3 & 4.1 & 27.1 & 16.6 & 4796 & 4.6 & 8.0 & 2.8 \\
\hline & STD & 3.0 & 1.2 & 2.1 & 1.2 & 2.0 & 4.6 & 409 & 0.4 & 0.0 & 0.3 \\
\hline & Max & 38.4 & 18.0 & 37.5 & 6.2 & 30.4 & 24.0 & 5580 & 5.2 & 8.1 & 3.1 \\
\hline & Min & 28.0 & 14.0 & 30.4 & 2.8 & 24.4 & 10.0 & 4360 & 4.0 & 7.9 & 2.1 \\
\hline \multirow{4}{*}{$\begin{array}{l}\text { French aerated } \\
\text { wetland }\end{array}$} & Average & 15.8 & 8.3 & 30.1 & 0.9 & 25.1 & 16.6 & 327 & 7.4 & 8.3 & 1.5 \\
\hline & STD & 5.8 & 2.0 & 1.7 & 0.5 & 4.3 & 4.6 & 54 & 0.6 & 0.3 & 0.2 \\
\hline & Max & 25.6 & 12.0 & 32.9 & 1.9 & 31.4 & 24.0 & 402 & 8.0 & 8.7 & 1.8 \\
\hline & Min & 10.0 & 6.0 & 27.7 & 0.2 & 18.4 & 10.0 & 259 & 6.2 & 7.9 & 1.2 \\
\hline
\end{tabular}



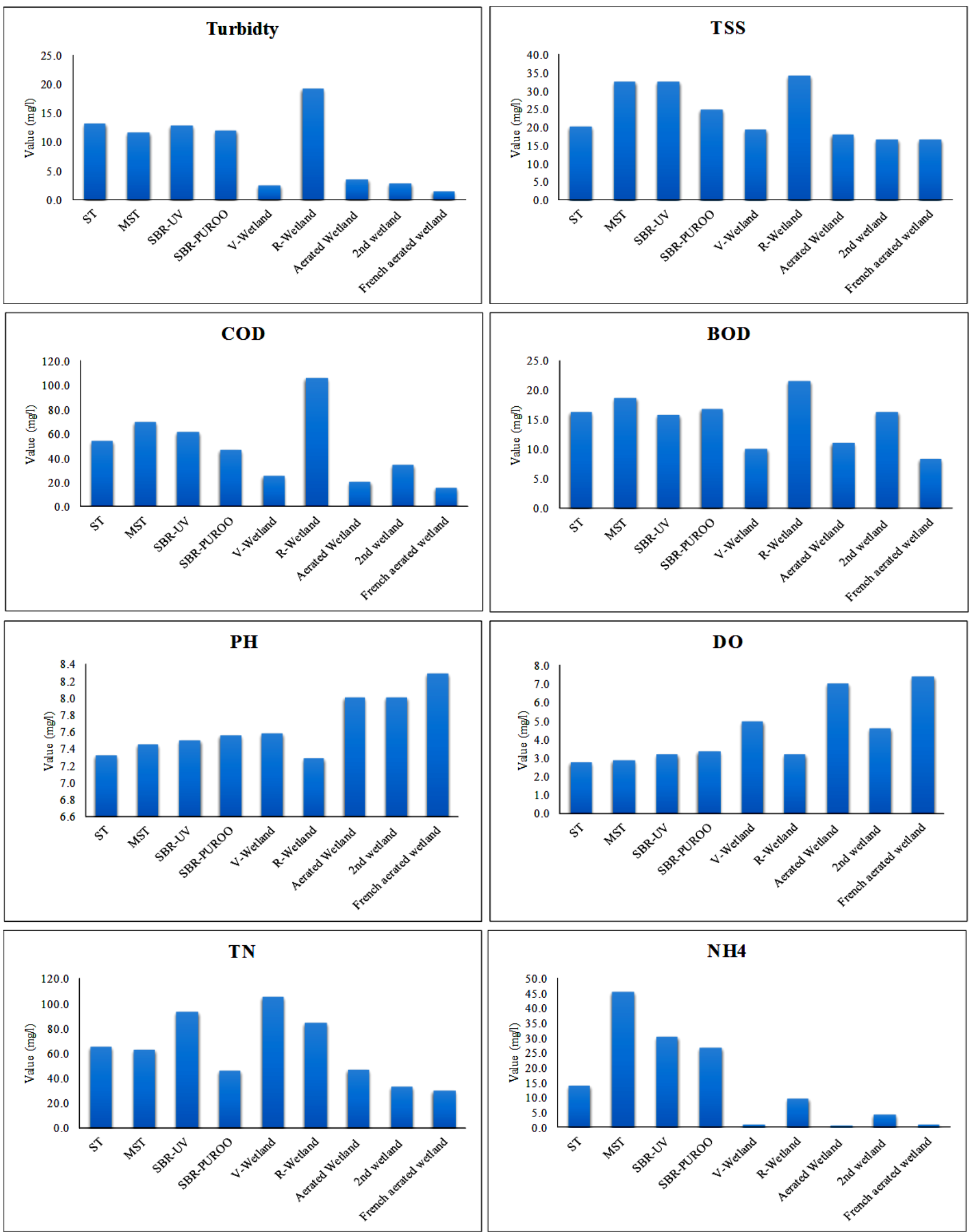

Fig. 1 Performance of different technologies 
Table 3 Removal efficiency (\%) and energy consumption (Jordan Dinar, JD)

\begin{tabular}{|c|c|c|c|c|c|c|c|}
\hline Technology & COD & BOD & $\mathrm{TN}$ & NH4 & E. Coli & TSS & Energy consumption $\left(\mathrm{JD} * / \mathrm{m}^{3}\right)$ \\
\hline Septic Tank & 94.1 & 97.4 & 99.5 & 49.14 & 79.4 & 97.47 & 0.30 \\
\hline Modified Septic Tank & 91.1 & 95.96 & 99.6 & 50.9 & 73.4 & 95.97 & 0.30 \\
\hline SBR-UV & 92.8 & 96.4 & 99.9 & 27.6 & 65.54 & 95.97 & 0.23 \\
\hline SBR-PUROO & 94.5 & 97.3 & 99.9 & 64.11 & 80.86 & 96.93 & 0.25 \\
\hline V-Wetland & 97.7 & 98.8 & 99.9 & 38.1 & 68.72 & 97.6 & 0.05 \\
\hline R-Wetland & 92.7 & 96.5 & 99.6 & 34.14 & 75.72 & 95.74 & 0.08 \\
\hline Aerated Wetland & 97.5 & 99.03 & 99.9 & 63.75 & 89.18 & 98.79 & 0.03 \\
\hline 2nd wetland & 96.5 & 98.6 & 99.9 & 74.1 & 94.03 & 98.89 & 0.03 \\
\hline French aerated wetland & 98.1 & 99.3 & 99.9 & 76.55 & 92.6 & 99.44 & 0.04 \\
\hline
\end{tabular}

$1($ Jordanian Dinar, $J D)=1.4097$ USD

The removal efficiency follows the same trend for the different parameters but with different magnitudes. For example, E-Coli has the highest removal efficiency which is promising followed by TSS which is very important since the water re-use normally practiced using dripping irrigation. Lessor no TSS helps in avoiding pipes clogging. Overall, this similarity in removal pattern for all the parameters indicates consistency in the treatment processes for the nine technologies and therefore, more selection criteria are necessary to choose the best option. Energy consumption is one possible selection criterion. Finally, and concerning the treated wastewater standards, the efficiency of each technology was calculated as the percentage of removal. This indicator reflects the ability of each technology to remove the loads and hence to purify the wastewater. The effluent was compared to standards category $\mathrm{A}, \mathrm{B}$, and $\mathrm{C}$ to ensure the reliability of treated wastewater but also as a measure of efficiency. Table 4 shows the treated wastewater standards.

Table 4 Treated wastewater reuse standards

\begin{tabular}{|c|c|c|c|c|c|c|c|c|c|c|}
\hline Standards & COD & BOD & $\mathrm{TN}$ & NH4 & $\mathrm{NO}_{3}$ & TSS & E. coli & DO & $\mathrm{pH}$ & Turbidity \\
\hline Irrigation-Class B & 500.0 & 200.0 & 70.0 & N/A & 45.0 & 200.0 & 1000 & N/A & 9.0 & N/A \\
\hline Artificial recharge & 50.0 & 15.0 & 45.0 & 5.0 & 30.0 & 50.0 & 2 & 2.0 & 9.0 & 2.0 \\
\hline
\end{tabular}

Figure 2 shows a pictorial representation of the possible relationship between COD and BOD for the nine investigated technologies. Although the points are only nine and not enough to establish strong statistical significance, still we can have an idea about the possible correlation between COD and BOD. These significant correlations indicate that the processes are working successfully and the collected samples and analysis are valid. COD tends to follow COD in wastewater treatment processes. On the other hand, TN is significantly correlated with NH4 indicating efficient nitrogen removal. However, a good amount of nitrogen remains in the treated wastewater which is good for re-use. Overall, this high level of removal ensures hydrologic system protection, both when we discharge the treated wastewater to rivers, or when we use for irrigation. The quality of the treated wastewater is suitable for groundwater recharge (Hubbard et al., 2016). However, this statement needs more analysis and not within the scope of this paper. 

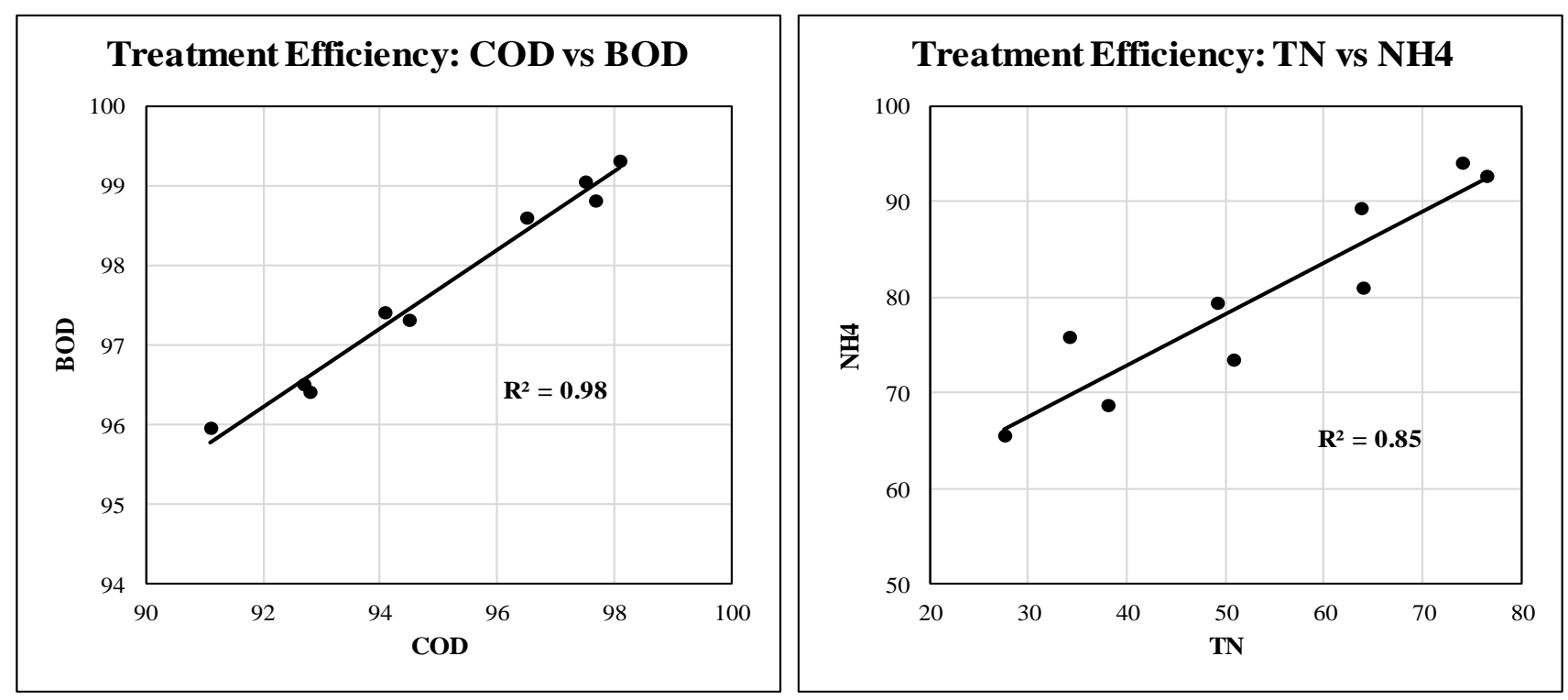

Fig. 2 Treatment efficiency (\%) for COD vs BOD (left) and $\mathrm{TN}$ vs $\mathrm{NH}_{4}$ (right) for nine technologies

\section{Conclusions}

Adopting decentralized wastewater treatment options has great potential for protecting soil and water resources from contamination. Cesspits continue to pollute water resources in Jordan, especially in rural areas, and hence an integrated water resources plan should include decentralized wastewater as one of its alternative strategies to consider wastewater as an opportunity rather than a challenge. Most of the renewable groundwater resources in Jordan are distributed within karst limestone aquifers which are highly vulnerable to contamination by raw wastewater. The collection and on-site treatment of raw water will certainly alleviate the potential contamination of soil and groundwater. As an output of this research, the results show clearly that the investigated technologies perform well for organic matter removal and nitrification and make sludge management easy. Following are five lessons learned:

1- Three years of continuous monthly data is considered a decent amount of data to examine the performance of decentralized wastewater treatment technologies. The collected monthly data over three years allowed us to derive solid conclusions and reliable results. However, it is difficult to compare the technologies concerning their costs because it depends on the local economic conditions.

2- Centralized wastewater options are not feasible in rural areas where communities are scattered. Hence, adopting decentralized wastewater treatment options will certainly protect the hydrologic system; surface water and groundwater, and will provide treated wastewater for supplementary irrigation and therefore alleviate the stress on domestic water resources.

3- The collected data is proven consistent and reliable, and hence we can build solid conclusions and decisions on the analysis, especially for the comparison between the different technologies in terms of their performance. Wetland technologies seem to be more feasibly subject to the availability of space.

4- The energy consumption varies from 0.04 to $0.30 \mathrm{JD}$ per cubic meter of treated wastewater. This is not the only cost item, operation and maintenance require additional cost too. Overall, the cost varies across different technologies but the wetland system is more economically feasible.

5- Treatment was very efficient in terms of E-Coli and TSS which are the most important parameters. Also, technologies show consistency in their performance which makes the decision on the best technology easier. The excellent removal of E-Coli ensures health protection and the removal of TSS ensures efficient irrigation systems with less maintenance.

Finally, if we consider the German experience, nearly 1.5 million decentralized wastewater treatment units are installed in rural areas, mainly to protect the hydrologic system. In Jordan, there are approximately 240 units mostly operating in houses, farms, hotels, and police offices in remote areas. This is a humble number and cannot help protect our hydrologic and environmental systems. This research shows the successful efficiency of the various technologies under Jordanian conditions using a scientific approach based on 
observations rather than estimations or simulations. The future in Jordanian rural areas is certainly for decentralized wastewater treatment technologies, and this is proven as a successful approach to protecting the hydrologic system.

\section{Acknowledgments}

The author would like to acknowledge SMART Project - Sustainable Management of Available Water Resources with Innovative Technologies, funded by the German Federal Ministry of Education and Research (BMBF) and implemented by Al-Balqa Applied University in collaboration with Helmholtz Environmental Research Center (UFZ) in Leipzig Germany, and the Jordanian Ministry of Water and Irrigation (MWI). Also, I would like to thank Al-Balqa Applied University for making their laboratories and transportation available during this research.

\section{Nomenclature}

$\begin{array}{lll}\text { Acronyms } & & \\ \mathrm{AS} & =\text { Activated Sludge } & {[-]} \\ \mathrm{BOD} & =\text { Biochemical Oxygen Demand } & {[-]} \\ \mathrm{COD} & =\text { Chemical Oxygen Demand } & {[-]} \\ \mathrm{CSTR} & =\text { Continuous stirred-tank reactor } & {[-]} \\ \mathrm{E} & =\text { Effluent } & {[-]} \\ \mathrm{OF} & =\text { Overflow } & {[-]} \\ \mathrm{PD} & =\text { Pre-Denitrification } & {[-]} \\ \mathrm{S} & =\text { Dissolved material concentration } & {[\mathrm{mg} \text { COD/l] }} \\ \mathrm{SE} & =\text { particulates separation coefficient } & {[-]} \\ \mathrm{Si} & =\text { Dissolved material concentration in the feed } & {[\mathrm{mg} \text { COD/l] }} \\ \mathrm{SI} & =\text { Soluble inert organics concentration } & {[\mathrm{mg} \text { COD/l] }} \\ \mathrm{TKN} & =\text { Total Kjeldahl Nitrogen } & {[-]} \\ \mathrm{UF} & =\text { Underflow } & {[-]} \\ \mathrm{W} & =\text { Waste } & {[-]}\end{array}$

\section{References}

Abbassi, B., Abuharb R., Ammary, B., Almanaseer, N., and Kinsley, C. "Modified Septic Tank: Innovative Onsite Wastewater Treatment System" Water, 10, 578, 2-11 (2018)

Almanaseer, N., and, Sankarasubramanian A. "Role of Climate Variability in Modulating the Surface Water and Groundwater Interaction over the Southeast United States", J. of Hydro. Eng., 17, 1001-1010 (2012)

Ambica A., and Raman, K. "Wetland Wastewater Treatment System for Small City Suburbs-A Review". Indian J. of Sci. and Techn., 8, 1-5 (2015)

Beuna, J., Hendriksa, A., Loosdrechta, M., Morgenrothb, E., Wildererb P., and Heijnena J. "Aerobic granulation in a sequencing batch reactor" Water Research, 33, 2283-2290 (1999)

Brunner, N., Starkl, M., Kazmi, A., Real, A., Jain, N., and Mishra, V. “Affordability of Decentralized Wastewater Systems: A Case Study in Integrated Planning from India" Water, 10, 1644, 1-27 (2018)

Burde, M., Rolf, F., and Grabowski, F. "Innovative low cost procedure for nutrient removal as an integrated element of decentralized water management concept for rural areas", Water Sci. and Techn., 44, 105-112 (2001)

Chong M., Sharma, M., Burn, A., and Saint, C. "Feasibility study on the application of advanced oxidation technologies for decentralized wastewater treatment", J. of Cleaner Prod., 35, 230-238 (2012)

Esser, D., Stéphane, T., and Salma, F. "Constructed Wetlands for the treatment of raw wastewater: The French experience", Water Prac. and Tech., 9, 430439 (2014)

Fach, S., and Fuchs, S. "Design and development of decentralized water and wastewater technologies: a combination of safe wastewater disposal and fertilizer production”, Water Sci. and Tech., 62, 1580-1586 (2010)

Hubbard, L., Keefe, S., Kolpin, D., Barber, L., Duris, J., Hutchinson, K., and Bradley, P. "Understanding the hydrologic impacts of wastewater treatment plant discharge to shallow groundwater: Before and after plant shutdown", Envi. Sci. Water Res. and Tech., 2, 864-874 (2016)

Hussein, H., "An analysis of the framings of water scarcity in the Jordanian national water strategy", Water Inter., 44, 6-13, (2019)

Hussain, I., Muscolo, A., Farooq, M., and Ahmad, W. "Sustainable use and management of non-conventional water resources for rehabilitation of marginal lands in arid and semiarid environments", Agri.. Water Manag., 221, 462-476 (2019)

Khattiyavong, C., and Lee, H. "Performance Simulation and Assessment of an Appropriate Wastewater Treatment Technology in a Densely Populated Growing City in a Developing Country: A Case Study in Vientiane, Laos". Water, 11, 1012-1028 (2019)

Massoud, M., Tarhini A., and Nasr, A. "Decentralized approaches to wastewater treatment and management: Applicability in developing countries", J. of Env. Manag., 90, 652-659 (2008) 
Masia, F., and Martinuzzi, N. "Constructed wetlands for the Mediterranean countries: hybrid systems for water reuse and sustainable sanitation”, Desalination, 215, 44-55 (2007)

M.W.I , Jordan Ministry of Water and Irrigation, "Decentralized Wastewater Management Policy”, (2016)

M.W.I , Jordan Ministry of Water and Irrigation "National Water Strategy 2016-2025" (2019)

Nanninga, T., Bisschops, I., Lopez, E., Martinez, J., Murillo, D., Essl, L., and Stark1, M. "Discussion on sustainable water technologies for peri-urban areas of Mexico City: balancing urbanization and environmental conservation", Water, 4, 739-758 (2012)

Prost-Boucle, S., and Molle, P. "French vertical-flow constructed wetlands in mountain areas: how do cold temperatures impact performances", Water Sci. and Tech.., 71, 1219-1228 (2015))

Singh, N., Kazmi, A., and Starkl, M. "A review on full-scale decentralized wastewater treatment systems: techno-economical approach", Water Sci Tech., 71,468-478 (2014)

Vymazal, J., "Horizontal sub-surface flow and hybrid constructed wetlands systems for wastewater treatment", Eco. Eng., 25, 478-490 (2005)

Vymazal, J., "Constructed Wetlands for Wastewater Treatment", Water, 2, 530-549 (2010)

Wang, Y., Wu, L., and Engel, B. "Prediction of Sewage Treatment Cost in Rural Regions with Multivariate Adaptive Regression Splines" Water, 11, 195, 2$18,(2019)$ 